\title{
Fatality Fire of the Unemployment Hills: Fatality Tendency and Job Search Tools 1
}

Kamil ORHAN (http://orcid.org/0000-0002-0232-5306), Department of Labour Economics and Industrial Relations, Pamukkale University, Turkey; e-mail: korhan@pau.edu.tr

\section{İşsizlik Dağının Kaderci Ateşi: Kadercilik Eğilimi ve İş Arama Yöntemleri²}

\begin{abstract}
It was searched whether there was any interaction between job search and fatalistic tendency, especially at support and job search processes. In this study, Fatalism Tendency Scale and the special designed demographic analysis form were used. 236 women and 210 men participated in the study. According to the results, fatalism tendency increases with age, decreases with income level and education. However, those with high fatalism tendency are observed to use fewer job search tools. High fatalism tendency group is more likely to use social relations or apply to corporate external agents while low fatalism group prefers direct methods and newspaper advertisements more intensively.

Keywords : : Unemployment, Psychological Effects of Unemployment, Fatalistic Tendency Scale, Fatalism.

JEL Classification Codes : $\quad$ E24, J64.

\section{$\ddot{\mathbf{O z}}$}

Çalışmada, işsizlik, istihdam ve iş arama süreçlerinde kadercilik eğiliminin etkisini sorgulanmaktadır. İş arama ve kaderci eğilim arasında, özellikle de destek ve iş arama süreçlerinde herhangi bir etkileşim olup olmadığı araştırılmıştır. Kadercilik Eğilimi Belirleme Ölçeği ve demografik analiz formu kullanılmıştır. Araştırmaya 236 kadın ve 210 erkek katılmıştır. Sonuçlara göre, kadercilik eğilimi, yaş arttıkça artmakta, gelir seviyesi ve eğitim arttıkça düşmektedir. Bununla birlikte, kadercilik eğilimi yüksek olan kişiler daha az sayıda iş arama aracı kullanmaktadır. Yüksek Kadercilik Eğilimli grup, sosyal ilişkileri kullanma veya İŞKUR gibi kurumsal dışsal aracılara daha çok başvururken; Düşük Kaderci grup doğrudan yöntemleri ve gazete ilanlarını daha yoğun tercih etmektedir.
\end{abstract}

Anahtar Sözcükler $\quad$ : İşsizlik, İşsizliğin Psikolojik Etkileri, Kadercilik Eğilimi.

I This article is the revised and extended version of the paper presented in " ${ }^{\text {th }}$ International Annual Meeting of Sosyoekonomi Society” which was held by Sosyoekonomi Society and CMEE - Center for Market Economics and Entrepreneurship of Hacettepe University, in Vienna/Austria, on October 27-28, 2017.

2 Bu makale Sosyoekonomi Derneği ile Hacettepe Üniversitesi Piyasa Ekonomisini ve Girişimciliği Geliştirme Merkezi tarafindan Avusturya'nın Viyana şehrinde, 27-28 Ekim 2017 tarihlerinde düzenlenen "Dördüncü Uluslararası Sosyoekonomi Derneği Yıllık Buluşması”nda sunulan çalışmanın gözden geçirilmiş ve genişletilmiş halidir. 


\section{"Ethos anthropos daimon" (Character is fate) - Herakleitos.}

\section{Introduction}

One of the most important issues of working life is employment. Employment, creates significant consequences both individually and socially. For this reason, one of the most emphasized issues of national or transnational corporations and organizations that guide the labor market is unemployment. Its social psychological consequences as well as the structure of the unemployment, effects of the economy and society are being searched. The most important social damage that the unemployment cause on the individual is the psychological health. In the short term, unhealthy deviations can be experienced in the minds of unemployed individuals. Many studies confirm this reality. It is also pointed out that the way to find a job and to find a solution to the unemployment is also important.

The work occupies a central place in the life cycle for an individual. For an individual, the sources of financial and social possession determined largely by the "job" to which his/her is working. In modern life, one of the most basic time-building tool of the individual is the working life. A daily life plan is created based on the time schedule of the job. In this sense, "job" is the basic mean of structuring our time. The "job" that is worked determines current and potential financial opportunities. In its concise definition, unemployment refers to the deprivation from the ability to the construction of life. It is inevitable that, when the "job" is defined as demonstrated occupation and effort, the unemployment is perceived as lack of endeavor and engagement (Tinar, 2013).

It is important for the Turkish societies' fatalistic thinking in the perception of unemployment, and its deepening, and size of the effects it creates. In this work, the fatalistic tendency on unemployment, employment and job search processes have been inquired.

\section{Unemployment Fact}

The experience of unemployment leads to the lack of financial and social resources as well as impossibilities of structuring them. For this reason, the experience of unemployment has been researched many times in the literature, and its effects have been highly emphasized. According to TURKSTAT;

"Within the reference period, at least one of the job search channels has been used within the last three months to seek employment from persons who are not employed (profit-making, casual, paid or unpaid work). All the people in the era of non-institutional work that can do business are unemployed" (TUIK, 2017).

According to the ILO, we can define individuals who are unable to find such an opportunity, but who are able to work or who are able to employ themselves in the reference period, but are unemployed (OECD, 2017). The unemployed comprise all persons of 
working age who were: a) without work during the reference period, i.e. were not in paid employment or self-employment; b) currently available for work, i.e. were available for paid employment or self-employment during the reference period; and c) seeking work, i.e. had taken specific steps in a specified recent period to seek paid employment or self-employment (ILO, 2017). For these institutions, showing the job search behavior and using at least one of the job search channels is an important parameter.

In general, in the literature the destructive and negative effects of the experience of individual and social unemployment are discussed. However, it is also stated that the level of the effect of the unemployment experience differs among the individuals. The role of the individuals in the working life, the economic and social distress experienced in unemployment, and whether finding financial and social support, seems important in the emergence of individual differences. Especially, the existence and quality of social support is more important.

Because of its nature, inertia is destroyer and destructive. The fact that there is no work that an individual can work and is productive leads to poverty and injustice on the social side, but it also creates psychological problems from the individual point of view (K1cir, 2017). On this basis, there are major psychosocial problems that pose serious risks to society. There is a wide negative impact involving both employees and their families. Uncertainty and job insecurity have a direct negative impact on employee health, triggering psychosomatic health problems and suicidal tendencies (European Commission, 2010) or indirectly affecting suicidal tendencies (Platt, 1984). According to Murphy and Athanasou (1999) meta analysis study, the results of 14 researchers confirm this scientific fact.

Surveys show that the unemployed individuals have an increased likelihood of experiencing depression and stress-related syndromes (Kokko \& Pulkkinen, 1998), a decrease in the sense of well-being (Andersen, 2009), self-esteem (Kokko \& Pulkkinen, 1998), tendency to leave the workplace (Lee \& Mitchell \& Sablynski \& Burton, 2004). Along with such psychological problems, physical health deteriorates and marriages become worse. Even it is found that having economic problems have been found to lead directly to divorce (Broman \& Hamilton \& Hoffman, 1997), separation in cohabiting couples (Roy, 2011), with the consequences of job losses. It also increases the use of drugs and alcohol (European Commission, 2010; Perreault \& Touré \& Perreault \& Caron, 2017).

In long term studies, the effects of unemployment are more clearly defined. Having a satisfactory job has been found to have higher self-esteem, lower depressive effect, less externality, and lower negative emotional state than unemployment (Winefield \& Winefield \& Tiggemann \& Goldney, 1991). A similar study found that employees who were unemployed or who did not have a satisfactory job had poorer performances (Winefield \& Tiggemann \& Winefield, 1991).

In general, while findings support this, Young (1985) found no link between selfesteem and the duration of unemployment, unemployment and the length of the anomaly. Definitely, in times of high unemployment rates, the destructive effect is even greater. In 
particular, mental and physical health of women is more exposed to adverse effects of unemployment (Drydakis, 2015). Unemployed men tend to blame themselves and others and they show catastrophic behavior (Extremera \& Rey, 2014). It has also been determined that the lifelong unemployment experience may have a long-term effect in the 50's (Daly \& Delaney, 2013).

\subsection{Coping with Unemployment}

At the strategies applied to cope with unemployment, for an individual to take action, to act or to learn the helplessness seems to be an important factor. However, the existence or the lack of financial and social support is important. After the loss of work, family and financial support was found to have a positive effect on the psychological health of men (Shams, 1993). Low financial support increases a low sense of well-being and psychosocial problems 6-7 times. When high stress is experienced, finding high financial and social support reduces the likelihood of being in good health to 2-3 times, and the increase in psychosomatic syndromes to 3-4 times (Åslund \& Larm \& Starrin \& Nilsson, 2014: 230).

Welfare stigmatas are influential on the individual's analytical behavior in the face of unemployment. There is an inverted $U$ shape. Foreseeing low employability, the individual puts off prosperity and intensive job search for a long time (deterrent effect). On the other end, once the aid is received, those entering the welfare level increasingly reduce their job seeking efforts by facing low employability (Contini \& Richiardi, 2012). When the working men face unemployment, they have difficulty in entering perspectives, planning, positive refocusing and taking perspective (Extremera \& Rey, 2014: 6-7). The situation becomes more serious with the information that employees can access more hidden or open job opportunities (Gnambs \& Stiglbauer \& Selenko, 2015) than the unemployed, and the effect of unemployment deepens. In this aspect of our work, we are trying to explain the extent to which the fatalistic tendency is effective in the job search process of the individual.

\subsection{Job Search Process}

Job search is a purposeful and willing behavior manifested in a determined manner in order to be employed. In this process, the individual uses different and alternative sources and engages in various activities to reach his or her own goal (Kanfer \& Wanberg \& Kontrowitz, 2001: 838). It is up to the individual to carry out the successful applicant process which can reach him or her to the employment and hence ending the unemployment process. At this point, the job search strategy that the individual chooses is gaining importance. Choosing the right strategies accelerates the process of getting employed (Piróg, 2016: 567). Similar to the cases that are beased on self-regulated behaviors, in the job seeking process, self-management creates individual differences.

As in the cases of based on self-regulated behaviors, as in the job seeking process, phenomena related to self-management create individual differences (Kanfer \& Wanberg \& Kontrowitz, 2001: 838). 
The intensity and diversity of job search processes is determined by psycho-social factors which largely effect the likelihood of reaching the desired outcome. For example, a worker anticipating a call back from the former employer spends less effort and time than somebody else not having such a possibility (Krueger \& Mueller, 2010). Fatalism tendency also plays such a role in making differences between individuals in terms of the number of attempts, intensity and importance of the means that the individual uses in job search processes.

\subsection{Fatalism and the Fatalistic Tendency}

In general, in the literature, it is stated that there is a positive correlation between the personal features such as self-esteem (Judge \& Bono, 2001), self-efficacy (Saks \& Ashforth, 1999; Moynihan \& Roehling \& LePine \& Boswell, 2003), proactiveness (Brown \& Cober \& Kane \& Shalhoop, 2006), being outgoing and responsible (Tziner, 2004; Turban \& Stevens \& Lee, 2009) high intrinsic control (Caliendo \& Cobb-Clark \& Uhlendorff, 2015; Plumly \& Oliver, 1987) and having social support (Ellis \& Taylor, 1983) with the intensity of job search behavior and the number of attempts effecting the ultimate success. Studies carried out mostly in western cultures express that there is no significant link between such concepts and job search activities in oriental cultures (Bao \& Luo, 2015).

The fatalistic tendency is, briefly, "a world view that the events and actions are determined by an external force and that the root cause is not in the man's capability" (Orhan, 2017). Fatalistic people believe that they do not have control over their own lives. Fatalism and locus of control concepts are closely related and has the potential to become a general informal institution that explains many areas of human behavior (Kouba, 2016). With a fatalistic approach, people tend to explain events that they live with external agents. Unemployment is also a difficult event for the individual to cope with and is difficult to explain to himself. The length of unemployment increases the focus on external control (Young, 1985). From this point of view, it seems that on the perceiving and coping with unemployment experiences, fatalistic approaches are likely to be effective.

In this study, the beliefs of unemployed people on job search channels and their intensity of consumption of job search channels (how much they used or the frequency of use behaviors) were considered as job search behaviors. The extent to which job seeking behavior is influenced by individuals' fatalism tendencies has been analyzed. The study addresses the job search behavior exhibited for exit from unemployment from a fatalism perspective. Individuals are thought to be involved in interacting with the fatalism of the perceptions of the unemployment process.

\section{Materials and Methods}

Materials: In our study, the fatalistic tendency was measured by the Fatalism Tendency Scale developed by Orhan (2017), while the demographic characteristics were determined by using a questionnaire developed specifically for this study. Considering easy accessibility, it is mainly applied to unemployed individuals. The Fatalism Tendency Scale 
is a form consisting of 15 questions to be evaluated in a 5-point Likert style. All the questions are straight and there is no opposite expression. Points are obtained from 4 subscales of Fatalism Tendency Scale (Fatalism Tendency Scale-General, [Kadercilik Ölçeği Genel Puanı: KEBÖ], Lack of Control [Kontrol Yoksunluğu İnancı: KYI], Destinity / Predetermined Belief [Alınyazısı/Önceden Belirlenmişlik İnancı: AOB], Luckiest Approach [Talihçi Yaklaşım: TAI], Irrational Causal Relationship [İrrasyonel Sebep Sonuç İlişkisi: ISSI]). Cronbach Alpha score in the reliability study for the whole scale was 0,84 ; and 0,84 ; 0,$82 ; 0,71 ; 0,57$ for the sub-dimensions. It has been understood that the Fatalistic Tendency Scale has a high but significant but moderate correlation with the Rotter's Self-Esteem Scale $\left(\mathrm{r}_{(648)}=, 47 \mathrm{p}=, 000\right)$ and Kontrol Odağ Ölçeği $(\mathrm{r}(649)=56 \mathrm{p}=, 000)$. Structural Equation Model analysis of the scale also shows that a practical model has been constructed for use. $\left(\mathrm{CFA}\left[\chi^{2}{ }_{(81)}=224,81 ; p<, 000, \chi^{2 / d f}=2,77 ; \mathrm{IFI}=0,95 ; \mathrm{TLI}=0,94 ; \mathrm{NFI}=0,93 ; \mathrm{CFI}=\right.\right.$ $0,95$; RMSEA $=0,52]$ ). Demographic questions include personal information such as gender, age, employment status, as well as information on which job search channels employ to unemployed individuals and how effective they are.

Participants: A total of 462 persons (236 women, 210 men) participated in the study at the age range between $17-58$ years $($ M. $=29,33 ;$ S. D. $=8,19) .43 \%$ of the sample is under the age of 26 . The sample is mostly graduated from university $(42,0 \%)$, high school $(20,1 \%)$ or (\% 20) lower middle school education; they see themselves in the middle-income group (79\%). The singles were $(64,5 \%)$; who are not currently working were $(89,6 \%)$, and job seekers were (72.3\%). Have been searching for jobs for 6 months on average (ranj, 1-60 months, S.D. $=8,18$ ). In this period, the proportion of those receiving partly or completely financial support from the social environment is $61,7 \%$ and the proportion of social support is $73.5 \%$. The rate of rejecting a job offer made in this period is about half $(49,7 \%)$.

\section{Findings}

The demonstration of job search behavior and effective use of the methods in this process are important indicators for defining unemployment. In this context, the effective usage of the methods play an important role.

Table: 1

The Frequency of Job Seekers' Use of Job Search Channels and Perception of Effectiveness towards These Channels

\begin{tabular}{|c|c|c|c|}
\hline & $\mathrm{N}$ & $\%$ & Activity Score Avg. \\
\hline Direct application to business & 259 & 62,56 & 3,56 \\
\hline Online applications & 238 & 57,48 & 3,28 \\
\hline Close relatives of workplace employees & 221 & 53,38 & 3,46 \\
\hline Recommendations of workplace employees & 209 & 50,48 & 3,20 \\
\hline İŞKUR & 162 & 39,13 & 3,24 \\
\hline Newspaper Advertisements & 120 & 28,98 & 2,63 \\
\hline Educaitonal institutions & 89 & 21,49 & 2,20 \\
\hline Temporary occupational recruitment & 82 & 19,80 & 2,65 \\
\hline Private employment offices & 68 & 16,42 & 2,98 \\
\hline Television Advertisements & 66 & 15,94 & 1,61 \\
\hline Magazine Advertisements & 65 & 15,70 & 1,64 \\
\hline Radio Advertisements & 53 & 12,80 & 2,23 \\
\hline Working in a foreign country & 35 & 8,45 & 1,83 \\
\hline Other & 5 & 1,20 & 2,53 \\
\hline
\end{tabular}


As seen from the table, direct applications to businesses $(62,56 \%)$ are the most frequently used job search methods. At the same time, direct applications are also considered to be the most effective $(\mathrm{M}=3,58 ; \mathrm{SD}=1.05)$. Moreover, the recommendations of both relatives $(\mathrm{M}=3,46 ; \mathrm{SD}=1,15)$ and other employees $(\mathrm{M}=3,20 ; \mathrm{SD}=1.16)$ working in the same place are also commonly used and are considered to be effective. Besides, it is observed that online system applications are made more frequently, and they are considered to be effective $(M=3,28 ;$ S.D. $=1,14)$. İSKUR is also considered as an effective job search method $(M=3,24 ; S D=1,30)$. Newspaper advertisements, on the other hand, seem to be relatively weak. Besides institutional communication networks and the existence of public organizations such as IŞKUR, the use of relative and social relations means of getting employed is noteworthy. This situation in Turkey, in many respects is thought to be a reflection of the dual structures. On the one hand, while the use of traditional methods is perceived to be fast and effective, contemporary systems are also used. Five point scale (one general and four dimension points) obtained from the Fatalism Tendency Scale is tested by normal distribution tests and it is observed that normal distribution conditions are attained. Accordingly, for the KEBÖ, the Kolmogorov-Smirnov distribution (D (462) =0,035; p = $0,20)$ shows a normal distribution. The dimensions were also considered to be normal distribution by controlling the Skewness and Kurtosis thresholds (Tabachnick \& Fidell, 2013) (KYI S =0,67; $\mathrm{K}=0,63$; AOB $\mathrm{S}=0,84 ; \mathrm{K}=0,04$; TAI $\mathrm{S}=0,38 \mathrm{~K}=-0,54$; ISSI $\mathrm{S}=$ $0,26 ; K=0,58)$. The mean scores obtained from these five points are given in Table 2 .

Table: 2

KEBÖ, KYI, AOB, TAI and ISSI Points of the Sample

\begin{tabular}{lccc}
\hline & N & Mean & Std. Deviation \\
\hline Destinity / Pre-determined Belief (AOB) & 462 & 3,70 & 1,06 \\
Lack of Control (KYI) & 462 & 2,29 & 1,12 \\
Irrational Causal Relationship (ISSI) & 462 & 2,56 &, 96 \\
Luckiest Approach (TAI) & 461 & 2,35 &, 98 \\
Fatalism Tendency Scale-General (KEBÖ) & 462 & 2,83 &, 73 \\
\hline
\end{tabular}

According to this, the fatalistic tendency of the sample is relatively higher than that of the fatalistic control $(M .=3,48)$. However, the lowest mean score $(M=2,29)$ is observed in the sample for lack of control in terms of dimensions. The mean score of general fatalism score is found as 2,83 .

Figure: 1

Age Groups and Fatalism Tendency

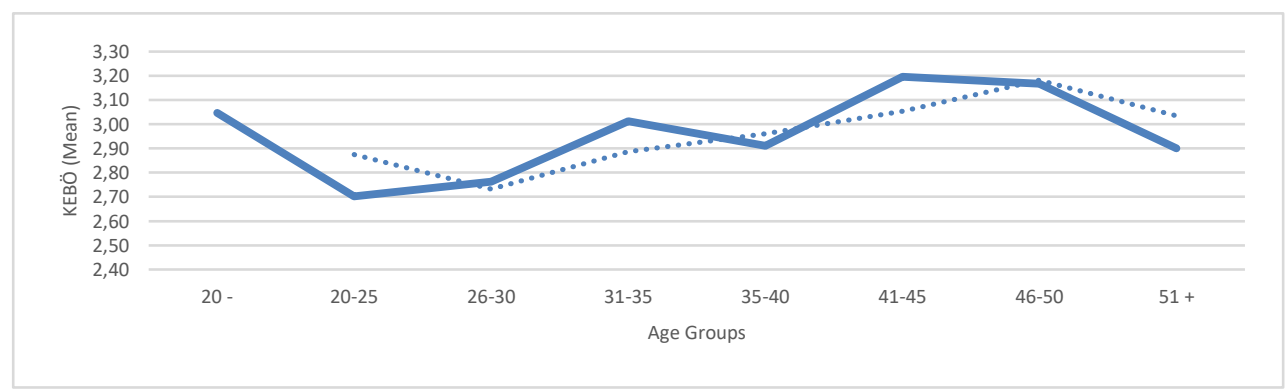


The graph of age groups (Figure 1) shows fluctuations in the KEBÖ mean.

If the trend for "moving distribution" is added to the graph, then first the falling of the high tendency of fatalism for the ages under 20 years old, next rising for ages 26-30 years old and above, and again falling back for ages over 50 years old are observed. The Fatalistic Tendency Scale-General score and the Irrational Causal Relationship (ISSI) subscale (F (7, $453)=2,07 ; \mathrm{p}=.045$ ) differ significantly in terms of age groups. According to the analysis performed, the 21-30 age group has less fatalistic tendencies than the 31-50 age group (except the 36-40 age group) (Table 3).

Table: 3

Age and Education Groups Analysis for Fatalism Scale (ANOVA Test)

\begin{tabular}{|c|c|c|c|c|c|c|c|}
\hline AGE & & Sum of Squ. & df & Mean Squ. & $\mathrm{F}$ & Sig. & Post hoc (Age groups) \\
\hline \multirow{3}{*}{ ISSI } & Between Groups & 13,41 & 7 & 1,91 & 2,07 &, 045 & $21-25<41-45,46-50$ \\
\hline & Within Groups & 418,71 & 453 & ,92 & & & $26-30<46-50$ \\
\hline & Total & 432,12 & 460 & & & & \\
\hline \multirow{3}{*}{ KEBÖ } & Between Groups & 12,30 & 7 & 1,75 & 3,31 & ,002 & $21-25<31-35,41-45,46-50$ \\
\hline & Within Groups & 239,87 & 453 &, 53 & & & $26-30<31-35,41-45,46-50$ \\
\hline & Total & 252,17 & 460 & & & & \\
\hline \multicolumn{2}{|c|}{ EDUCATION } & Sum of Squ. & df & Mean Squ. & $\mathrm{F}$ & Sig. & Post hoc (Education gro.)* \\
\hline \multirow{3}{*}{ AOB } & Between Groups & 23,66 & 3 & 17,30 & 16,70 & 0,000 & $\mathrm{E}>\mathrm{H}, \mathrm{U}$ \\
\hline & Within Groups & 246,32 & 457 & 1,03 & & & $\mathrm{~S}<\mathrm{H}, \mathrm{U}$ \\
\hline & Total & 269,98 & 460 & & & & $\mathrm{H}<\mathrm{U}$ \\
\hline \multirow{3}{*}{ KYI } & Between Groups & 42,18 & 3 & 14,06 & 11,93 & 0,000 & $\mathrm{E}>\mathrm{H}, \mathrm{U}$ \\
\hline & Within Groups & 538,59 & 457 & 1,17 & & & $\mathrm{~S}<\mathrm{U}$ \\
\hline & Total & 580,77 & 460 & & & & $\mathrm{H}<\mathrm{U}$ \\
\hline \multirow{3}{*}{ ISSI } & Between Groups & 49,01 & 3 & 16,33 & 19,47 & 0,000 & $\mathrm{E}>\mathrm{H}, \mathrm{U}$ \\
\hline & Within Groups & 383,42 & 457 & 0,83 & & & $\mathrm{~S}<\mathrm{U}$ \\
\hline & Total & 432,43 & 460 & & & & $\mathrm{H}<\mathrm{U}$ \\
\hline \multirow{3}{*}{ TALI } & Between Groups & 49,01 & 3 & 10,18 & 11,13 & 0,000 & $\mathrm{E}>\mathrm{H}, \mathrm{U}$ \\
\hline & Within Groups & 383,42 & 457 & 0,91 & & & $\mathrm{~S}<\mathrm{U}$ \\
\hline & Total & 432,43 & 460 & & & & $\mathrm{H}<\mathrm{U}$ \\
\hline \multirow{3}{*}{ KEBÖ } & Between Groups & 43,50 & 3 & 14,50 & 31,74 & 0,000 & $\mathrm{E}>\mathrm{H}, \mathrm{U}$ \\
\hline & Within Groups & 208,77 & 457 & 0,45 & & & $\mathrm{~S}<\mathrm{H}, \mathrm{U}$ \\
\hline & Total & 252,28 & 460 & & & & $\mathrm{H}<\mathrm{U}$ \\
\hline \multicolumn{2}{|l|}{ INCOME } & Sum of Squ. & df & Mean Squ. & $\mathrm{F}$ & Sig. & Post hoc (Income gro.) ${ }^{* *}$ \\
\hline \multirow{3}{*}{ AOB } & Between Groups & 5,48 & 2 & 6,74 & 6,03 & 0,003 & $\mathrm{~L}>\mathrm{M}, \mathrm{Hi}$ \\
\hline & Within Groups & 264,60 & 459 & 1,11 & & & $\mathrm{M}>\mathrm{Hi}$ \\
\hline & Total & 270,08 & 461 & & & & \\
\hline \multirow{3}{*}{ KYI } & Between Groups & 56,74 & 2 & 28,37 & 24,84 & 0,000 & $\mathrm{~L}>\mathrm{M}, \mathrm{Hi}$ \\
\hline & Within Groups & 524,24 & 459 & 1,14 & & & $\mathrm{M}>\mathrm{Hi}$ \\
\hline & Total & 580,99 & 461 & & & & \\
\hline \multirow{3}{*}{ ISSI } & Between Groups & 18,09 & 2 & 9,05 & 10,02 & 0,000 & $\mathrm{~L}>\mathrm{M}, \mathrm{Hi}$ \\
\hline & Within Groups & 414,35 & 459 & 0,90 & & & $\mathrm{M}>\mathrm{Hi}$ \\
\hline & Total & 432,45 & 461 & & & & \\
\hline \multirow{3}{*}{ TALI } & Between Groups & 18,09 & 2 & 9,02 & 10,55 & 0,000 & $\mathrm{~L}>\mathrm{M}, \mathrm{Hi}$ \\
\hline & Within Groups & 414,35 & 459 & 0,93 & & & $\mathrm{M}>\mathrm{Hi}$ \\
\hline & Total & 432,45 & 461 & & & & \\
\hline \multirow{3}{*}{ KEBÖ } & Between Groups & 24,02 & 2 & 12,01 & 24,15 & 0,000 & $\mathrm{~L}>\mathrm{M}, \mathrm{Hi}$ \\
\hline & Within Groups & 228,29 & 459 & 0,50 & & & $\mathrm{M}>\mathrm{Hi}$ \\
\hline & Total & 252,31 & 461 & & & & \\
\hline
\end{tabular}

* E = Elemantary School; $S=$ Secondary School; $H=$ High School; $U=$ University.

** L = Low Income Level, $M=$ Middle Income Level, Hi = High Income Level.

Considering the fatalistic tendencies of the generations in the framework of generation theory, it is observed that the $\mathrm{X}$ generation exhibits more fatalistic tendencies (Table 3).

The same holds true for both the general score; KEBÖ $\left(\mathrm{t}_{(117,85)}=-4,05 ; \mathrm{p}=, 000\right)$; and for dimensions; AOB $\left(\mathrm{t}_{(458)}=-2,78 ; \mathrm{p}=, 006\right)$; KYI $\left(\mathrm{t}_{(458)}=-2,58 ; \mathrm{p}=, 010\right)$; ISSI $(\mathrm{t}$ 
$(105,46)=-2,77 ; \mathrm{p}=, 006)$ and TALI $\left(\mathrm{t}_{(102,54)}=-2,03 ; \mathrm{p}=, 041\right)$. In general, gender is not a statistically significant difference on fatalism score $\left(\mathrm{t}_{(441,88)}=0,85\right)$, although women have lower mean scores than men (M. = 2,79) $-1,19 ; \mathrm{p}=, 231)$. However, it is observed that there is a differentiation only in the KYI dimension (Table 4).

Table: 4

Fatalism $\mathbf{t}$ Test Results for Generations

\begin{tabular}{|c|c|c|c|c|c|c|c|}
\hline \multicolumn{2}{|c|}{ Generation } & $\mathrm{N}$ & Mean & Std. Deviation & $\mathrm{t}$ & df & Sig. (2-tailed) \\
\hline \multirow{2}{*}{$\mathrm{AOB}$} & Y Generation & 383 & 3,63 & 1,09 & \multirow[t]{2}{*}{$-2,78$} & \multirow[t]{2}{*}{458} & \multirow[t]{2}{*}{0,006} \\
\hline & $\mathrm{X}$ Generation & 77 & 4,00 & 0,84 & & & \\
\hline \multirow{2}{*}{ KYI } & Y Generation & 383 & 2,23 & 1,10 & \multirow[t]{2}{*}{$-2,58$} & \multirow[t]{2}{*}{458} & \multirow[t]{2}{*}{0,010} \\
\hline & X Generation & 77 & 2,59 & 1,17 & & & \\
\hline \multirow{2}{*}{ ISSI } & Y Generation & 383 & 2,51 & 0,95 & \multirow[t]{2}{*}{$-2,77$} & \multirow[t]{2}{*}{105,46} & \multirow[t]{2}{*}{0,006} \\
\hline & $\mathrm{X}$ Generation & 77 & 2,85 & 1,00 & & & \\
\hline \multirow{2}{*}{ TALI } & Y Generation & 383 & 2,31 & 0,96 & \multirow[t]{2}{*}{$-2,06$} & \multirow[t]{2}{*}{102,54} & \multirow[t]{2}{*}{0,041} \\
\hline & X Generation & 77 & 2,58 & 1,06 & & & \\
\hline \multirow{2}{*}{ KEBÖ } & Y Generation & 383 & 2,77 & 0,74 & \multirow[t]{2}{*}{$-4,05$} & \multirow[t]{2}{*}{117,85} & \multirow[t]{2}{*}{0,000} \\
\hline & $\mathrm{X}$ Generation & 77 & 3,11 & 0,66 & & & \\
\hline \multirow{2}{*}{ KYI } & Men & 236 & 2,42 & 1,12 & \multirow[t]{2}{*}{2,11} & \multirow[t]{2}{*}{444} & \multirow[t]{2}{*}{0,035} \\
\hline & Women & 210 & 2,20 & 1,12 & & & \\
\hline
\end{tabular}

Education seems to be another important factor in the perception of fatalism $\left(\mathrm{F}_{(3,457)}\right.$ $=31,74 ; \mathrm{p}=.000)$.

The tendency of fatalism is effected by education as observed in both in AOB $\left(\mathrm{F}_{(3 \text {, }}\right.$ 457) $=14,70 ; \mathrm{p}=.000) ; \operatorname{KYI}\left(\mathrm{F}_{(3,457)}=11.93 ; \mathrm{p}=, 000\right) ; \operatorname{ISSI}\left(\mathrm{F}_{(3,457)}=19,47 ; \mathrm{p}=, 000\right)$ and TALI $\left(\mathrm{F}_{(3,457)}=11,13 ; \mathrm{p}=, 000\right)$ dimensions.

According to Post Hoc Analysis (LSD), in general, as education increases, the fatalistic tendency decreases. The socio-economic status of the family is statistically different in terms of KEBÖ $\left(\mathrm{F}_{(2,459)}=24,15 \mathrm{p}=, 000\right)$ and subscales of $\mathrm{KYI}\left(\mathrm{F}_{(2,459)}=24,84\right.$ $\mathrm{p}=, 000), \operatorname{AOB}\left(\mathrm{F}_{(2,459)}=6,03 \mathrm{p}=, 009\right)$, ISSI $\left(\mathrm{F}_{(2,459)}=10,02 \mathrm{p}=, 000\right)$ and TALI $\left(\mathrm{F}_{(2,459)}\right.$ $=10,55 \mathrm{p}=, 000)$. As the socio-economic level increases, the fatalistic tendency decreases (Table 3). In addition, they have more fatal tendencies than those who have children (M. = $3,05 ; \mathrm{SD}=0,72)(\mathrm{M} .=2,70 ; \mathrm{SD}=0,71), 92, \mathrm{p}=, 000)$. There was no significant change in the tendency of fatalism in terms of the duration of unemployment.

As the socio-economic level increases, the fatalistic tendency decreases (Table 3). In addition, those with children (M. $=3,05$; S.D. $=0,72)$ compared to those without children $(M .=2,70 ;$ S.D. $=0,71)$ have more tendency towards fatalism $\left(t_{(318,97)}=-4,92 ; p=, 000\right)$. There was no significant change in the tendency of fatalism in terms of the duration of unemployment.

When the relationship between the finding of financial support from the social environment and the tendency of fatalism is analyzed, It is understood that individuals who receive financial support $(M .=2,78 ;$ S.D. $=0,70)$ are less fatalistic than those who do not $(\mathrm{M} .=2,97 ;$ S.D. $=0,77)$ have this support $\left(\mathrm{t}_{(278,36)}=-2,52 ; \mathrm{p}=, 012\right)$. Also, when it is considered in terms of social support, the overall score of KEBÖ differs significantly between two groups $\left(\mathrm{t}_{(433)}=-3,06 ; \mathrm{p}=, 002\right)$. The group with social support $(\mathrm{M} .=2,79, \mathrm{SD}$ $=0,68$ ) exhibits a lower fatalism (without support; $\mathrm{M} .=3,05, \mathrm{SD}=0,84$ ). 
Many studies have repeatedly reported the link between the job seekers' method exhaustion and getting results. The fatalistic tendency also affects the use of job search methods $(\mathrm{F}(4,324)=3,30 ; \mathrm{p}=, 011)$. As a general fact, individuals who use less job search methods tend to be more fatalistic. Among the job seekers, the average fatalism score for those using only 1-2 job search channels is 2,97 , while the average fatalism score for those who said that they used all available methods is 2,71 .

In general, three different fatalism levels were formed from the mean $(\mathrm{M} .=2,83)$ and standard deviation $($ S. D. $=0,73)$ of fatalism scores: Low $(n=73)$, Medium $(n=313)$ and High $(\mathrm{n}=76)$ Fatalism Tendency Groups.

Table: 5

Fatalism Levels and Job Search Methods Effectiveness Perception

\begin{tabular}{|c|c|c|c|}
\hline & \multicolumn{3}{|c|}{ Fatalism Level } \\
\hline & Low & Middle & High \\
\hline Newspaper & 2,79 & 2,56 & 2,65 \\
\hline Magazine & 1,83 & 1,69 & 1,80 \\
\hline Radio & 2,80 & 2,27 & 2,17 \\
\hline Television & 1,60 & 1,73 & 1,38 \\
\hline Direct application & 3,75 & 3,66 & 3,49 \\
\hline İŞKUR & 3,62 & 3,26 & 3,14 \\
\hline Private Employment Agency & 3,63 & 3,03 & 3,00 \\
\hline Educational/Training Institution & 3,38 & 2,09 & 2,50 \\
\hline Employee Recommendation & 3,52 & 3,25 & 3,13 \\
\hline Close and Relative Recommendation from Workplace & 3,67 & 3,47 & 3,34 \\
\hline Temporary Employment & 2,40 & 2,71 & 3,00 \\
\hline Internet Applications & 3,42 & 3,29 & 3,00 \\
\hline Application of Working in Foreign Countries & 2,00 & 2,12 & 1,67 \\
\hline
\end{tabular}

Figure: 2

Fatalism Level and Efficiency of the Job Searching Methods

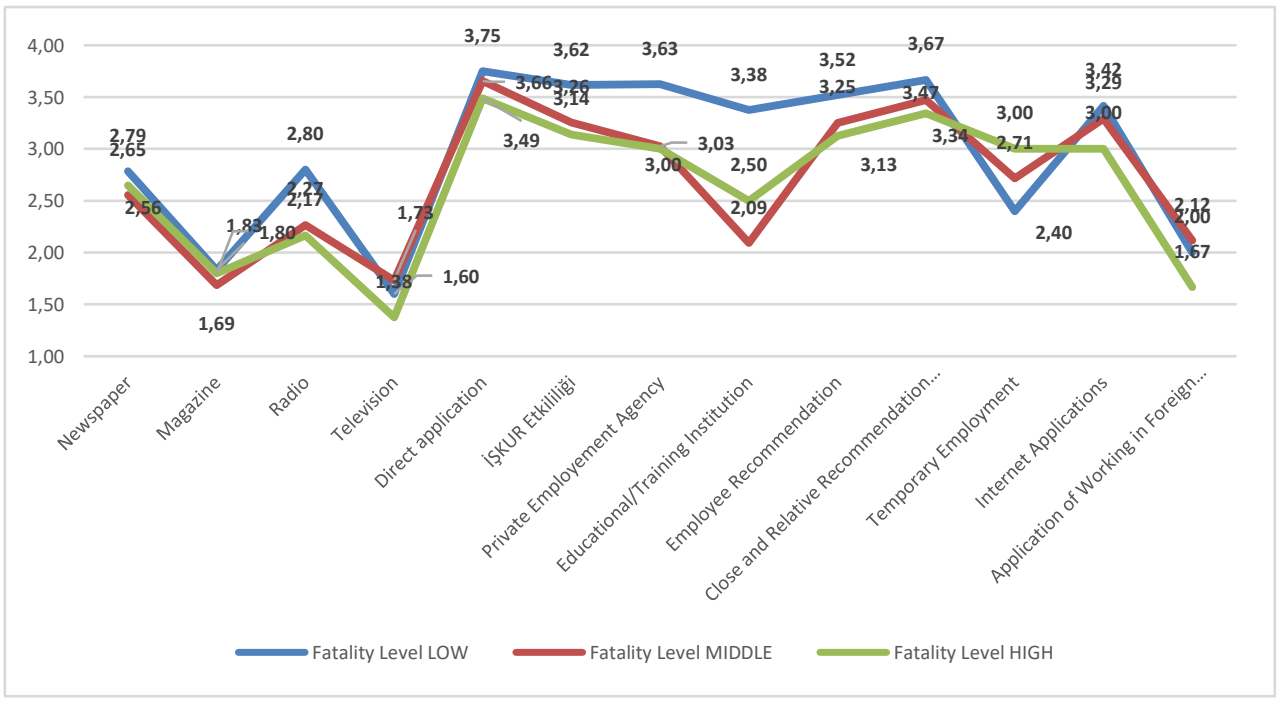


The evaluations of the effectiveness of job search methods of groups with high and low fatalistic levels are compared.

In general, 12 out of the 13 job search methods of the High Fatalistic Group (HFG) methods are found to be more effective by those in the Low Fatalistic Group (LFG). HFG (M. $=3,32 ;$ S.D. $=1,08)$ finds direct applications to businesses to be a more effective method $\left(\mathrm{t}_{(86,91)}=2,03 ; \mathrm{p}=, 045\right)$ compared to LFG (M. = 3,81; S.D. $\left.=1,18\right)$ (Figure 2).

Multidimensional Scaling Analysis has been applied considering the evaluation of the use of job search tools and the effectiveness of the tools in general. The distribution of the fatalistic scores is plotted with respect to the number of means used. The fatalistic levels of groups with different job search tool numbers are compared. For each group $(\mathrm{n}=$ not used at all, $a=1-2$ tool users, $b=3-4$ tool users, $c=5-6$ tool users, $d=7-10$ tool users, $e=$ more than 10 tool users) graphical presentations are derived separately, and then the graphs were combined to make it practical to visualize. The obtained $n$ (Stress $=0,00018, R^{2}=0.90$ ), a $\left(\right.$ Stress $\left.\left.=0,00000 ; R^{2}=0.86\right) 84\right), c\left(\right.$ Stress $\left.=0,00011 ; R^{2}=0.93\right), d\left(\right.$ Stress $=0,00031 ; R^{2}=$ $0,82)$ stress and $R^{2}$ value analysis show that the necessary conditions are met.

\section{Figure: 3}

\section{Multi Dimensional Scaling for Using Job Seeking Tools and Fatalism Tendency}

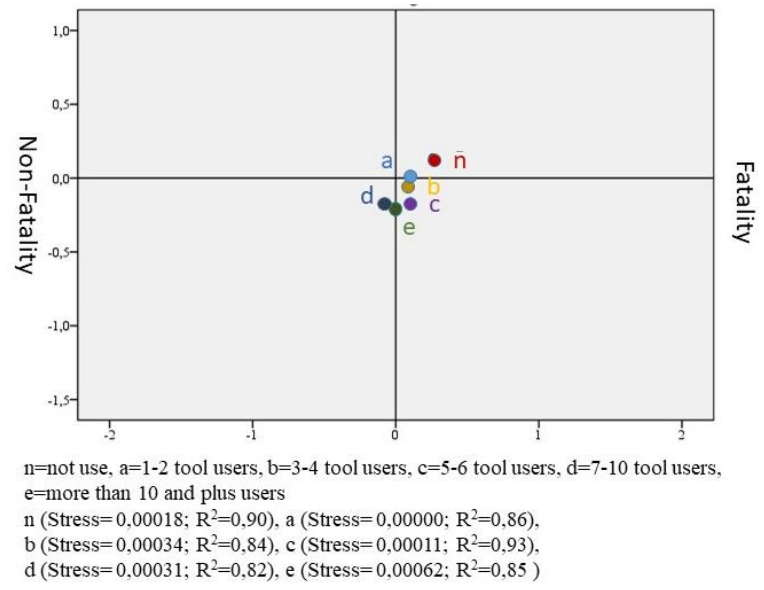

According to Figure 3, MDS analysis shows a negative relationship between Fatalism Tendency and job search tools use. Those who do not use any tool (n) have the highest, while those who use more than 10 tools (e) and 7-10 tools (d) have the lowest fatalistic tendency. The number of tools used by people with higher fatalistic tendencies is decreasing.

Similar findings have been frequently reported in studies on Locus of Control. According to Caliendo, Cobb-Clark, \& Uhlendorff (2010, 2015), individuals with an internal 
control focus are more likely to show job search behaviour. However, individuals who believe that their future will be determined by the external factors are less active.

In general, the preference of the methods used in search job processes by the sample are mapped (Figure 4). By evaluating this graph and considering the indicated methods in the analysis, the methods are separated into five logical groups. The first one is called "Media tools". Television, radio, newspaper and magazine application methods are put into the category of "Media tools". The second category is called "direct application tools". Direct applications from websites of companies or personally to companies are classified under this category. The third category includes the methods through individual referrals such as close relatives or relatives, or employees of the company. The category containing these methods is named "Social Relations". In the fourth category, the group formed by ISSKUR and private employment offices takes its place. The tools in this category are called "Employment Agencies". Finally, the category of "Training and Development Institutions" (Figure 4-6) is formed by the opportunities provided by foreign countries, institutions and educational institutions for temporary employment.

Figure: 4

Job Search Methods

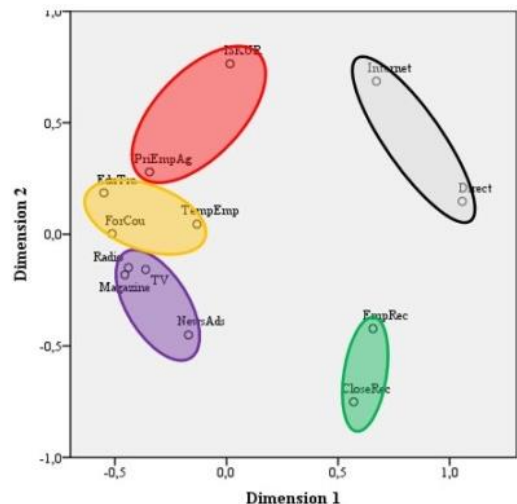

NewsAds:Newspaper

$\begin{array}{ll}\text { NewsAds:Newspaper } & \text { EmpRec:Employee Recommendation } \\ \text { Magazine:Magazine } & \text { CloseRec:Close and Relative } \\ \text { Radio:Radio } & \text { Recommendation from Workplace } \\ \text { TV:Television } & \text { TempEmp:Temporary Employment } \\ \text { Direct:Direct Application } & \text { Internet:Internet Applications } \\ \text { ISKUR:ISTUR } & \text { ForCou:Application of Working in } \\ \text { PriEmpAg:Private Employement } & \text { Foreign Countries } \\ \text { Agency } & \\ \text { EduTra:Educational/Training } & \\ \text { Institution } & \end{array}$

Taking these categories into account, the preferences of individuals for their job search tools are mapped on the basis of fatalistic tendency levels. The tools used in the job search processes are independently charted for both groups (Low and High Fatalism Groups). Another important issue is the means that individuals in low and high fatalistic 
tendency levels prefer to use. For this reason, another MDS analysis is used to analyse the distribution of the tools used (Figure 5-6).

\section{Figure: 5}

Favorites-Unfavorites Job Seeking Tools MDS Analysis for the Low Fatalism Tendency Group

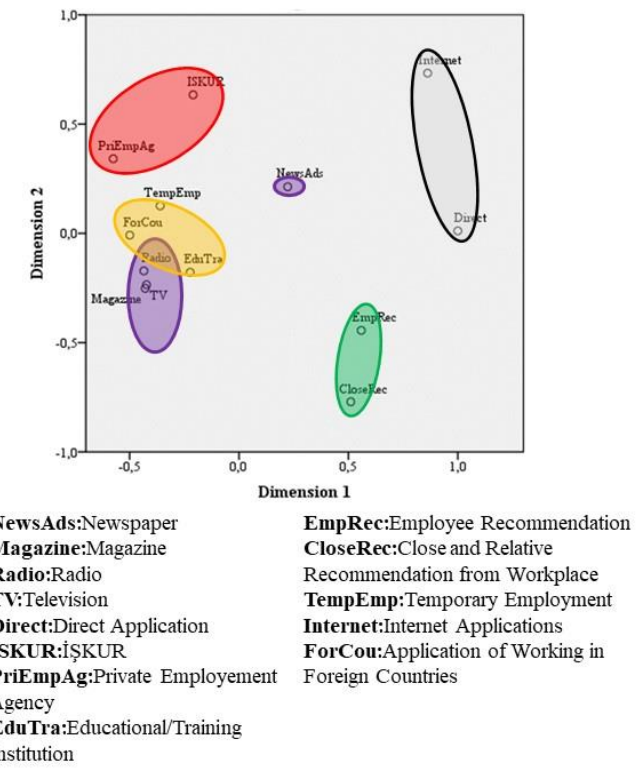

In Figure 5, the results of the Low Fatalistic Tendency group (Stress = 0,031; Tucker $=0,98$ ) that mostly prefers to use "Direct Application Methods" are given. This finding is parallel to the findings that there is a positive relationship between the general expectation of the individual and the intensity of job search behaviour presented in the literature (Kanfer, Wanberg, \& Kontrowitz, 2001: 842). Individuals who think they can achieve direct results in solving their own unemployment problems are using the direct application methods more intensely. "Media tools" seem to be the least favourite method. However, this group is more inclined to use newspaper advertisements. 


\section{Figure: 6}

\section{Favorites-Unfavorites Job Seeking Tools MDS Analysis for the High Fatalism Tendency Group}

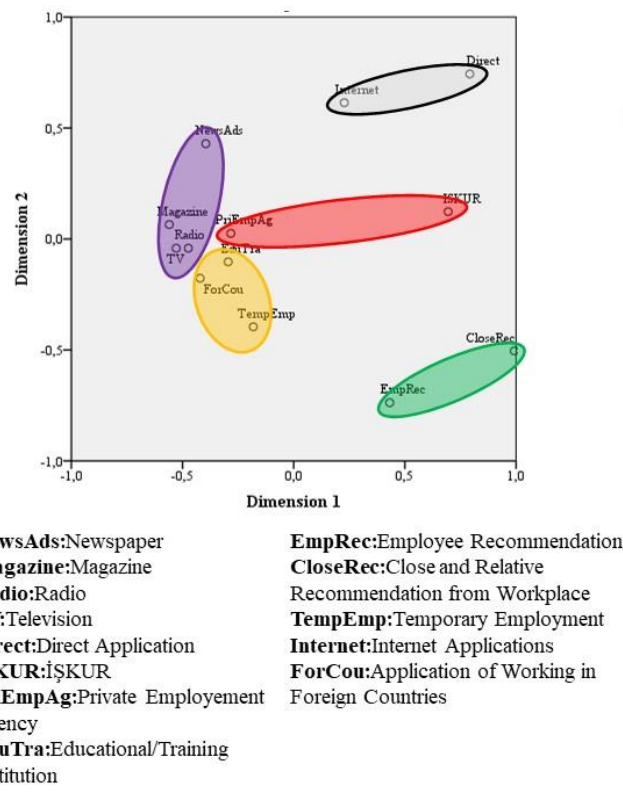

For the High Fatalistic Tendency Group (Stress $=0,030$; Tucker $=0,98$ ) the most prominent difference is the use of İsKUR. The preference rate of "media tools" is also higher. At the same time, methods based on "Social Relations" are also being used more frequently. Compared to the Low Fatalistic Tendency Group, methods based on "social relations" are used more frequently. Though reaching out to the employers through informal channels based on such social relations seems to be more effective, faster and more economical (Fernandez, Castilla, \& Moore, 2000), due to the high fatalistic tendencies they are turning to institutional or social external factors in solving their problems (Figure 6).

\section{Conclusion}

In the case of unemployment, the "job search behaviour" issue is an important cornerstone for solving this problem. Studies indicate that a quantitative increase in job search behaviour by the individual will increase employment. In the job search process, the individual should enrich the methods and tools used. The number of attempts, intensity and variety of methods used play a key role in being employed. In addition to many psychosocial factors, the effect of the fatalistic tendencies of individuals on the number of methods used has been studied. 
The most frequently used methods in the job search processes are analysed by the results of the Fatalistic Determination Scale (Orhan, 2107). Thus, the use of the thirteen methods in five categories (Media Tools: via TV, Radio, Newspaper and Magazine application methods; Direct Application Tools: applications to companies via online tools or personally; Social Relations: referrals by close relatives or relatives, or employers in the company; Employment Agencies: İŞKUR and private employment offices, EducationDevelopment Institutions) and their relations to fatalistic tendency have been tried to be explained.

The fatalistic tendency does not differ in terms of men and women. The tendency to fatalism appears to be a more fundamental factor in the society. However, in terms of age, the tendency of fatalism, which is quite high at the before the 20's, falls with time. Especially in the age period of 21-35 years it is quite fall. It increases as people gets older. As it is known, in the 40's, it is seen as a period in which the individual has peaked professionally and socially. During this summit, it seems that fatalists have devoted themselves to success by moving away from the trends.

In accordance with the general expectations, as the perceived income levels and education of families increase, the fatalistic tendencies are decreasing. Graduating from a university not only helps to create new job opportunities in the work force market but also helps to develop cognitive structures such as self-confidence and self-efficacy; hence creating awareness of alternative thinking that keeps fatalistic tendencies away. By externalizing control over uncertainty, it shows lower fatalistic tendencies. Over the time with education, as the ambiguities about the profession and social life are reduced and become clearer, the tendency of fatalism decreases by internalizing the audit focus.

There is no expectation about any difference between fatalism trends of those who are currently employed and those who are unemployed. It will be explained by more detailed studies that will be carried out on the data. The graphical analysis between job search duration and fatalism tendency shows that there is a tendency to increase the tendency of fatalism as the time passes. It seems that having or accessing financial or social resources also decreases fatalistic tendencies.

In general, it is observed that individuals with Higher Fatalistic Tendency use fewer methods, and those with Lower Fatalistic Tendency use more methods. In the overall sample, mostly direct referrals have been found to be preferred.

It is observed that the low-fatalistic groups prefer the direct application methods more dominantly. Apart from this, especially in terms of using newspaper advertisements, it differs significantly from the High Fatalistic Group. This group tends to use newspaper advertisements more often. In contrast, the media in general in Turkey, and especially newspapers do not effectively prepare and put sufficient care to their advertisements. Studies (Feldman, Bearden, \& Hardesty, 2006) show that the level of information disclosure in advertisements is important in terms of the tendency of candidates to apply. Advertisements 
that contain information regarding the company, specific context of the work, the nature of the work are considered more seriously by candidates.

On the other hand, individuals with higher fatalistic tendency consume fewer methods. They do not need to apply different tools because of possible negative selfassessments and anxious approaches. Among the methods they use, social relations are more prominent. Similarly, the likelihood of using İSKUR increases. This can be assessed in the form of submitting to the "situation" with a fatalistic approach, or attributing another external factor to finding a solution.

As it is well-known, cognitive behavioural skills also determine the outcomes that will be achieved during the job search processes. Cognitive behavioural skills reduce the incidence of lower levels of depression and increase the number of proposals for employment in the period following the application (Pfeifer \& Strunk, 2016: 599). In this sense, the fatalistic tendency reduces the tendency to act hence at the very beginning it becomes influential to the result.

The fatalistic tendency emerges as a common reality of individuals as a social reality. Although gender as a biological feature does not make any difference, the experiences of social life influence the fatalistic tendencies. The degree of fatalism also affects the quality and quantity of the efforts of the job searchers. This poses a threat to the future of the individual as well as to the effectiveness of public social policies.

It is important that the education system, especially the universities, must be structured in such a way that it has to save the individual from the fatalism, to develop analytical thinking and cognitive development. Fatalism fire as a social phenomenon shows us the mountain of unemployment as a huge social reality.

\section{References}

Andersen, S.H. (2009), "Unemployment and Subjective Well-Being”, Work and Occupations, 36(1), 3-25.

Åslund, C. \& P. Larm \& B. Starrin \& K.W. Nilsson (2014), "The buffering effect of tangible social support on financial stress: influence on psychological well-being and psychosomatic symptoms in a large sample of the adult general population", International Journal for Equity in Health, 13(1), 85.

Bao, Z. \& P. Luo (2015), "How college students' job search self-efficacy and clarity affect job search activities", Social Behavior and Personality: An International Journal, 43(1), 3951.

Broman, C.L. \& V.L. Hamilton \& W.S. Hoffman (1997), "The impact of unemployment on families", Michigan Family Review, Winter 1996, 83-91.

Brown, D.J. \& R.T. Cober \& K.L. Kane \& J. Shalhoop (2006), "Proactive personality and the successful job search: A field investigation with college graduates", Journal of Applied Psychology, 91(3), 717-726.

Caliendo, M. \& D.A. Cobb-Clark \& A. Uhlendorff (2010), "Locus of control and job search strategies", Bonn: IZA Discussion Papers, No. 4750. 
Caliendo, M. \& D.A. Cobb-Clark \& A. Uhlendorff (2015), "Locus of control and job search strategies", Review of Economics and Statistics, 97(1), 88-103.

Contini, D. \& M.G. Richiardi (2012), "Reconsidering the effect of welfare stigma on unemployment", Journal of Economic Behavior \& Organization, 84(1), 229-244.

Daly, M. \& L. Delaney (2013), "The scarring effect of unemployment throughout adulthood on psychological distress at age 50: Estimates controlling for early adulthood distress and childhood psychological factors", Social Science \& Medicine, 80, 19-23.

Drydakis, N. (2015), "The effect of unemployment on self-reported health and mental health in Greece from 2008 to 2013: a longitudinal study before and during the financial crisis", Social Science \& Medicine, 128, 43-51.

Ellis, R.A. \& M.S. Taylor (1983), "Role of self-esteem within the job search process", Journal of Applied Psychology, 68(4), 632.

European Commission (2010), Investing in well-being at work: Addressing psychosocial risks in times of change, Directorate-General for Employment, Social Affairs and Equal Opportunities, Belgium: European Commission.

Extremera, N. \& L. Rey (2014), "Health-related quality of life and cognitive emotion regulation strategies in the unemployed: a cross-sectional survey", Health and Quality of Life Outcomes, 12(1), 172.

Feldman, D.C. \& W.O. Bearden \& D.M. Hardesty (2006), "Varying the content of job advertisements: The effects of message specificity", Journal of Advertising, 35(1), 123 141.

Fernandez, R. \& E.J. Castilla \& P. Moore (2000), "Social capital at work: Networks and employment at aphone center", American Journal of Sociology, 105(5), 1288-1356.

Gnambs, T. \& B. Stiglbauer \& E. Selenko (2015), "Psychological effects of (non)employment: A cross-national comparison of the United States and Japan", Scandinavian Journal of Psychology , 56, 659-669.

ILO (2017), Unemployement Rate, <www.ilo.org: http://www.ilo.org/ilostatfiles/Documents/description_UR_EN.pdf> , 22.12.2017.

Judge, T.A. \& J.E. Bono (2001), "Relationship of core self-evaluations traits - self-esteem, generalized self-efficacy, locus of control, and emotional stability - with job satisfaction and job performance: A meta-analysis", Journal of Applied Psychology, 86(1), 80-92.

Kanfer, R. \& R.W. Wanberg \& T.M. Kontrowitz (2001), "Job search and employment: A personality-motivational analysis and meta-analytic review", Journal of Applied Psychology, 8(5), 837-855.

Kıcır, B. (2017), "Eğitimli Genç İşsizliği Üzerinden İşsizlik Kaygısına Bir Bakış”, Çalışma ve Toplum, 3, 1369-1396.

Kokko, K. \& L. Pulkkinen (1998), "Unemployment and Psychological Distress: Mediator Effects", Journal of Adult Development, 5(4), 205-217.

Kouba, L. (2016), “A Survey: Theory of Control and Welfare State Attitudes”, Procedia-Social and Behavioral Sciences, 220, 210-216.

Krueger, A.B. \& A. Mueller (2010), "Job search and unemployment insurance: New evidence from time use data", Journal of Public Economics, 94(3), 298-307. 
Lee, T.W. \& T.R. Mitchell \& C.J. Sablynski \& J.P. Burton (2004), “The effects of job embeddedness on organizational citizenship, job performance, volitional absences, and voluntary turnover", Academy of Management Journal, 47(5), 711-722.

Meer, P. (2014), "Gender, Unemployment and Subjective Well-Being: Why Being Unemployed Is Worse for Men than for Women", Social Indicators Research, 115(1), 23-44.

Moynihan, L.M. \& M.V. Roehling \& M.A. LePine \& W.R. Boswell (2003), “A longitudinal study of the relationships among job search self-efficacy, job interviews, and employment outcomes", Journal of Business and Psychology, 18(2), 207-233.

Murphy, G.C. \& J.A. Athanasou (1999), “The effect of unemployment on mental health”, Journal of Occupational and Organizational Psychology, 72(1), 83-99.

OECD (2017), International Labour Organization (ILO) Resolutions Concerning Economically Active Population, Employment, Unemployment and Underemployment, <https://stats.oecd.org/glossary/detail.asp?ID=2791>, 23.12.2017.

Perreault, M. \& E.H. Touré \& N. Perreault \& J. Caron (2017), "Employment Status and Mental Health: Mediating Roles of Social Support and Coping Strategies", Psychiatric Quarterly, September, 88(3), 501-514.

Pfeifer, B.J. \& D.R. Strunk (2016), “GettiBack to Work: Cognitive Behavioral Predictors of Depressive Symptoms and Job Search Success”, Journal of Clinical psychology, 72(6), 591-605.

Piróg, D. (2016), "Job search strategies of recent university graduates in Poland: plans and effectiveness", Higher Education, 71(4), 557-573.

Platt, S. (1984), "Unemployment and suicidal behaviour: a review of the literature”, Social Science \& Medicine, 19(2), 93-115.

Plumly, L.W. \& J.E. Oliver (1987), "The Locus of Control Attribute and the Job Search Process”, Psychological Reports, 61(3), 907-910.

Roy, S. (2011), “Unemployment Rate and Divorce”, Economic Record, September, 87, 56-79.

Saks, A.M. \& B.E. Ashforth (1999), "Effects of individual differences and job search behaviors on the employment status of recent university graduates", Journal of Vocational Behavior, 54(2), 335-349.

Shamir, B. (1984), "Self-Esteem and the Psychological Impact of Unemployment", Social Psychology Quarterly, 49(1), 61-72.

Shams, M. (1993), "Social support and psychological well-being among unemployed British Asian men", Social Behavior and Personality: An International Journal, 21(3), 175-186.

Tabachnick, B. \& L. Fidell (2013), Using Multivariate Statistics, $6^{\text {th }}$ ed. Boston: Pearson.

Tınar, M.Y. (2013), "İ̧̧ Çalışma Yaşamı ve İş Analizi”, A.Ö. Leman Bilgin içinde: Çalışma Psikolojisi, Eskişehir: Anadolu Üniversitesi Yayınları No: 2756.

TÜİK (2017), Hanehalkı Isşü̈cü Araştırması Mikro Veri Seti, <http://www.tuik.gov.tr/MicroVeri/Hia_2011/turkce/metaveri/tanim/index.html>, 27.12.2017.

Turban, D.B. \& C.K. Stevens \& F.K. Lee (2009), "Effects of Conscientiousness and Extraversion on New Labor Market Entrants' Job Search: The Mediating Role of Metacognitive Activities and Positive Emotions", Personnel Psychology, 62(3), 553-573.

Tziner, A.V. (2004), "Predictors of job search intensity among college graduates", Journal of Career Assessment, 12(3), 332-344. 
Winefield, A.H. \& M. Tiggemann \& H.R. Winefield (1991), “The psychological impact of unemployment and unsatisfactory employment in young men and women: Longitudinal and cross-sectional data", British Journal of Psychology, 82(4), 473-486.

Winefield, A.H. \& H.R. Winefield \& M. Tiggemann \& R.D. Goldney (1991), “A longitudinal study of the psychological effects of unemployment and unsatisfactory employment on young adults", Journal of Applied Psychology, 76(3), 424-431.

Young, W.D. (1985), "The Effect of Length of Unemployment on Self-Esteem, Locus of Control, and Anomy", The University of Tulsa, Dissertations. 
Orhan, K. (2018), "Fatality Fire of the Unemployment Hills: Fatality Tendency and Job Search Tools", Sosyoekonomi, Vol. 26(38), 171-189. 